\title{
New observations of the ornamented Doushantuo embryo fossils from the Ediacaran Weng'an Biota, South China
}

\author{
ZONGJUN YIN \& MAOYAN ZHU
}

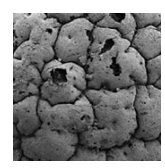

\begin{abstract}
Phosphatized Weng'an embryo fossils from the Ediacaran Doushantuo Formation in Guizhou, South China are dominated by various ornamented spheroidal fossils, with one internal body or several blastomeres enclosed within a single or multiple layered envelope, which have been interpreted as the resting eggs or diapause embryos of metazoans. Based on the microstructure of the envelope, we separated these ornamented spheroidal fossils into two groups: 1) group one, represented by typical Megasphaera ornata and characterized by an envelope consisting of at least two thick capsules with various surface ornaments and a single internal body, which can be interpreted as resting eggs; 2) another group, exhibiting an envelope consisting of a thin capsule with cell-like surface structure and internal blastomeres (amount is equal to $2^{\mathrm{n}}, \mathrm{n}=0,1,2,3 \ldots$ ), which are probably not diapause embryos but developing blastulae at various holoblastic cleavage stages. $•$ Key words: Ediacaran, Doushantuo, fossil, embryos, resting eggs, Weng'an Biota.
\end{abstract}

YIN, Z.J. \& ZHU, M.Y. 2012. New observations of the ornamented Doushantuo embryo fossils from the Ediacaran Weng'an Biota, South China. Bulletin of Geosciences 87(1), 171-181 (6 figures, 1 table). Czech Geological Survey, Prague. ISSN 1214-1119. Manuscript received September 12, 2010; accepted in revised form October 7, 2011; published online February 2, 2012; issued February 29, 2012.

Zongjun Yin \& Maoyan Zhu (corresponding author), State Key Laboratory of Palaeobiology and Stratigraphy, Nanjing Institute of Geology and Palaeontology, Chinese Academy of Sciences, Nanjing, 210008, China; myzhu@ nigpas.ac.cn

Since 1998, the phosphatized animal embryo microfossils with cellular and sub-cellular structures preserved in three-dimensional detail from the Ediacaran Doushantuo Formation at Weng'an phosphate mining area (Guizhou Province, southwest China), have been considered as one of the oldest fossil metazoan records on the planet (Li et al. 1998, Xiao et al. 1998, Condon et al. 2005). In spite of the fact that these Doushantuo embryo fossils are taphonomically biased (Chen 2004; Donbors et al. 2005, 2006), during the last decade, studies of animal fossils from this unique late Neoproterozoic taphonomic window have profoundly improved our outstanding of the evolution of multicellular animals in the Precambrian (Chen et al. 2000, 2002, 2004a, 2006, 2009a, b; Xiao \& Knoll 2000; Hagadorn et al. 2006; Xiao et al. 2007a, b; Liu et al. 2008). The different embryo sizes and ornamentations (Xiao \& Knoll 2000, Chen 2004), various embryo cleavage patterns (Chen 2004, Chen et al. 2006, 2009a) and potential fossil gastrulae (Chen et al. 2000, 2009a; Chen \& Chi 2005; Xiao et al. 2007a), as well as problematic animal adults (Xiao et al. 2000; Chen et al. 2002, 2004; Liu et al. 2008) indicate that the diversity of multicellular animals before the Cambrian radiation was much higher than previously thought.
Except for the large ancanthomorphic acritarchs, some of which may represent the diapause embryos of metazoans (Yin L. et al. 2007, Cohen et al. 2009), the spheroidal embryo fossils from the Weng'an Biota were assigned to three morphological genera and four morphospecies (Megasphaera ornata, M. inornata, Parapandorina raphospissa and Megaclonophycus onustus) according to the envelope ornamentations and amount of internal cells (Xiao \& Knoll 2000, Yuan et al. 2002). The morphological genus Megasphaera was established to describe the fossils without cell division. Based on the microstructure of the fossil envelope, this genus was further divided into two different morphospecies, M. ornata and M. inornata. The former is characterized by one cell enclosed within an ornamented envelope, while the latter refers to fossils with one cell encircled by a smooth envelope (Xiao \& Knoll 2000, Xiao et al. 2007b). Megasphaera has been regarded as a synonym of the acritarch genus Tianzhushania by Yin C. et al. (2004), whereby M. ornata and Tianzhushania tuberifera may represent the same taxon preserved in different lithological facies. However, Yin C. et al.'s opinion was not widely accepted due to a lack of fossil evidence (Xiao et al. 2007a, b, Yin L. et al. 2007, 2008). Another group of spheroidal embryos with more than one internal cell within 
a smooth or ornamented envelope was assigned to Parapandorina raphospissa and Megaclonophycus onustus (Xiao \& Knoll 2000, Xiao et al. 2007b).

Recent investigations indicate that the dominant Weng'an spheroidal microfossils possess an ornamented envelope, but only a few contain more than one internal cell (Yuan et al. 2002, Chi et al. 2003, Chen 2004, Xiao et al. 2007b, Chen et al. 2009a). All these ornamented spheroidal microfossils were interpreted to be metazoan eggs or embryos at a diapause stage (Xiao et al. 1998, Xiao \& Knoll 2000, Xiao et al. 2007b). However, this hypothesis was challenged by Chi et al. (2003) and Chen et al. (2009a), who interpreted the microfossils to be holoblastic blastomeres of embryos inside a sculptured envelope but not in the diapause stage. There two major reasons affect the interpretation of the Weng'an embryos. Firstly, these morphological taxa can be easily distinguished, however, the embryo fossils from different morphospecies may belong to different developmental stages of the same biological species, while different morphotypes of the same morphospecies may represent different biological species (Xiao \& Knoll 2000). Hence, assignation of these ornamented spheroidal microfossils to these morphological taxa leads to confusion in biological interpretations of Doushantuo embryos. Secondly, it is difficult to distinguish taphonomic and diagenetic artifacts from the primary bio-structures, such as cell shrinkage, degradation, loss of blastomeres and embryo capsules, multiple episodes of coating and lining, etc.

In order to reassess the Weng' an embryos, the present paper focuses on investigation of the ornamentation patterns and envelope microstructures of Megasphaera ornata and new specimens of Parapandorina raphospissa. In the light of comparisons with modern embryos, we discuss the biological properties of the ornamented and smooth envelopes of the Weng' an embryos, as well as their possible relationship to cytomembrane, fertilization membrane and diapause cyst of metazoan embryos.

\section{Materials and methods}

The Weng' an Biota is found in the Upper Phosphate Member (= Weng'an Phosphate Member) of the Doushantuo Formation in the Weng' an phosphate mining area of Guizhou Province, South China (Chen 2004, Chen \& Chi 2005, Dornbos et al. 2005, Zhu et al. 2007, Chen et al. 2009a). The Upper Phosphate Member consists of two different taphonomic facies, grey facies and black facies, represented by grey dolomitic phosphorite and black phosphorite, respectively (Chen \& Chi 2005; Dornbos et al. 2005, 2006). All the rock samples for this study were collected from the grey facies, and then digested in dilute acetic acid (acid concentration is between 5\% and 10\%). The inso- luble acid residue was then washed and dried. The liberated microfossils in the acid residue were checked under stereomicroscope and picked by hand with the help of a fine brush. Selected embryo fossils were examined with the scanning electron microscope. All the samples described in this paper are housed in Nanjing Institute of Geology and Palaeontology, Chinese Academy of Sciences.

\section{Taphonomic and morphological analysis of the ornamented embryos}

\section{Envelope ornamentation patterns of Megasphaera ornata}

The phosphatized embryos from the Weng' an Biota are dominated by microfossils with an ornamented envelope. The envelope is typically sculptured with various ornaments which are grouped into five types, including well-seamed polygons (Fig. 1A), polygons with fractal branching (Fig. 1B), tubercles (Fig. 1C), tubercles with dimples on top (Fig. 1D), and anastomosing ridges (Fig. 1E) (Xiao \& Knoll 2000, Yuan et al. 2002, Chen 2004). Recently, some large acanthomorphic acritarchs that coexist with the embryo fossils (e.g. Tianzhushania) have been considered to represent the diapause embryos of metazoans (Yin C. et al. 2004, Yin L. et al. 2007, Cohen et al. 2009). Thus, cylindrical processes on the envelope as exhibited by Tianzhushania should be considered to be another type of envelope ornamentation on the Doushantuo embryos. In fact, the morphological diversity of ornamentation pattern may be even higher as illustrated by Fig. 1H-J and Fig. 2A. In addition, some transitional forms between the ornamentation patterns mentioned above are very common (Fig. 1F, G, Xiao \& Knoll 2000). It should be noted that the range of preserved ornamentation patterns may be overestimated because of taphonomic artifacts. For example, the pitted ornament as shown by Fig. 1L differs greatly from any others shown in Fig. 1 and it may be just an imprint of ornaments on the inner capsule as shown by Fig. 1K, L.

Eggshell or embryo chorion ornamentation is a useful characteristic for classification of extant embryos at high taxonomic or even the species level (Gilbert \& Wurdak 1978, Belk 1989, Britz et al. 1995, Shen \& Huang 2008). In this regard, remarkable morphological variations of the envelope ornamentation patterns imply a relatively high evolutionary level for the metazoans in the Weng'an Biota.

\section{Ornamented spheroidal microfossils with cell-like structure}

Among the Weng'an ornamented embryos, one distinct form is the one with a thin envelope sculptured with small 

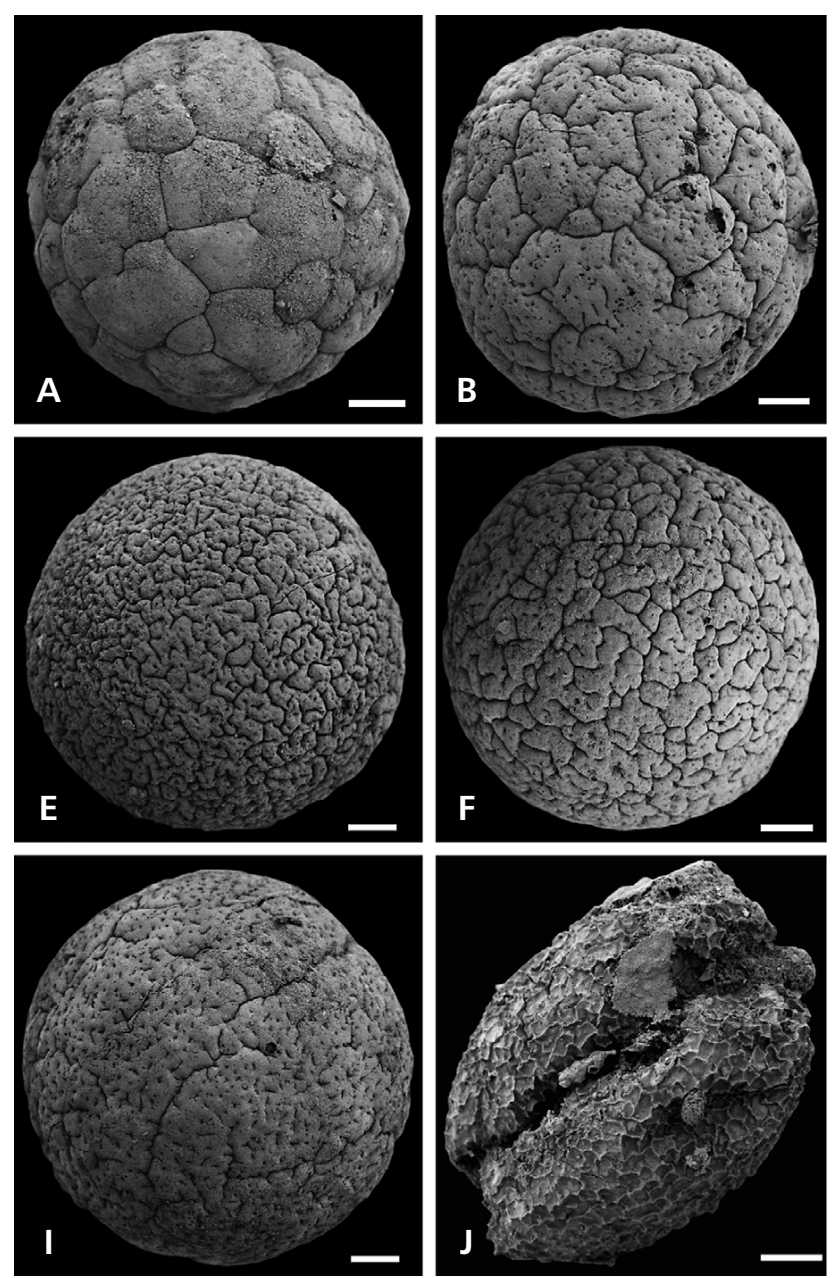
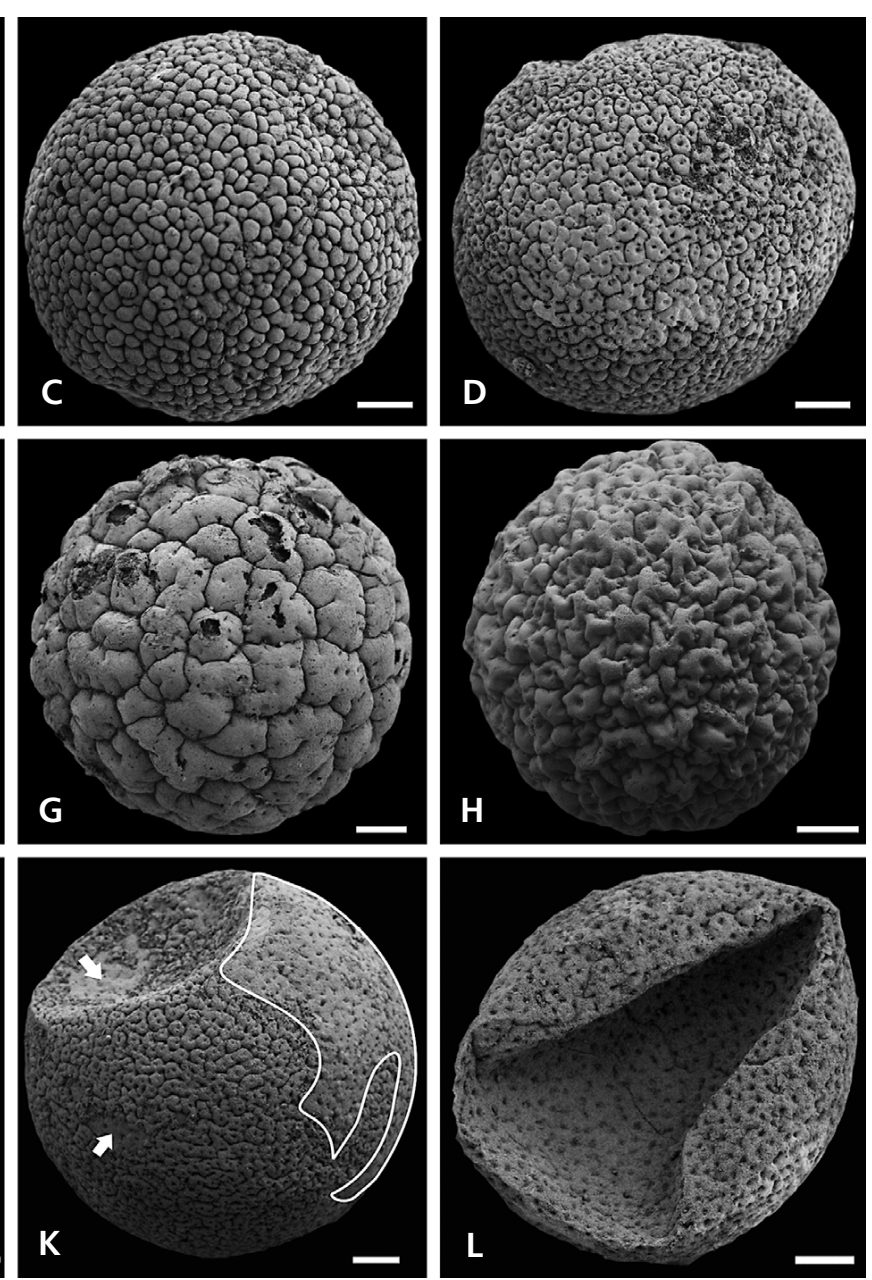

Figure 1. Ornamentation patterns of Megasphaera ornata from the Weng'an Biota. $\bullet$ A - polygons ornamentation. $\bullet$ B - polygons with fractal branching. $\bullet \mathrm{C}-$ smooth tubercles ornamentation. $\bullet \mathrm{D}$, tubercles with dimples on top. $\bullet \mathrm{E}-$ anastomosing ridges ornamentation. $\bullet \mathrm{F}$, G - transitional forms between $\mathrm{B}$ and $\mathrm{E}$. $\cdot \mathrm{H}-\mathrm{J}$ - microfossils with new ornamentation patterns. $\mathrm{H}$ - cerebral cortex-like ornamentation without clear anastomosing ridges; I - discontinuous furrows, short rod-shaped lines and dots; $\mathrm{J}$ - network ornamentation. $\bullet \mathrm{K}-\mathrm{a}$ bad-preserved fossil showing transitional pattern between $\mathrm{D}$ and $\mathrm{E}$, notice the imprinted ornamentation on the surface of exposed inner capsule (arrows and curve frame). $\bullet \mathrm{L}-$ pitted ornamentation looks similar to that on inner capsule of K. All the scale bars represent $100 \mu \mathrm{m}$.

regular polygons (Fig. 2A-G). Similar specimens have been illustrated previously, but they were considered to be the same as Megasphaera ornata in morphology and affinity (Yuan et al. 2002, Xiao et al. 2007b). Since the polygons are preserved in three-dimensional detail (Fig. 2K) and their shape is comparable to cell shape, Chen et al. (2009a) interpreted the polygons as the follicle cells of embryos. Although the follicle cell hypothesis has to be tested further (see conclusion section of this paper), one point can be affirmed that the cell-like structure is absolutely different from all other ornaments, not only because of its unique morphology but also its extreme stability of shape. The statistical investigation (Figs 3,4) indicates that the shape and size of these cell-like polygons are uniform in a single specimen and show only very slight variation among different specimens (Fig. 2A-I). In contrast, the shape and size of ornaments in other types are much more variable
(Fig. 1). Take ornamented microfossils with "well-seamed polygons" for example, in which the so called "polygons" have no constant size (Figs 3, 4), and the pattern of boundaries between them is highly irregular (Fig. 1A). Additionally, the variation in ornamentation is further evidenced by the transitional ornamentation forms (Fig. 1F, G).

Several new elongated specimens, two of them shown in Fig. 2F, G, show significant variation in the shape of the cell-like polygons in the equatorial part (Fig. 2J). We propose that the elongated shape represents developing deformation during mitosis from a one cell stage to a two-cell stage, and are not due to mechanical deformation. This interpretation is based on the following observations: 1) the elongated shape of the cell-like polygons only occurs in the equatorial part; 2) the elongation of the cell-like polygons shows gradual transition from the equator to the two poles; and 3) more importantly, all the elongated polygons are 

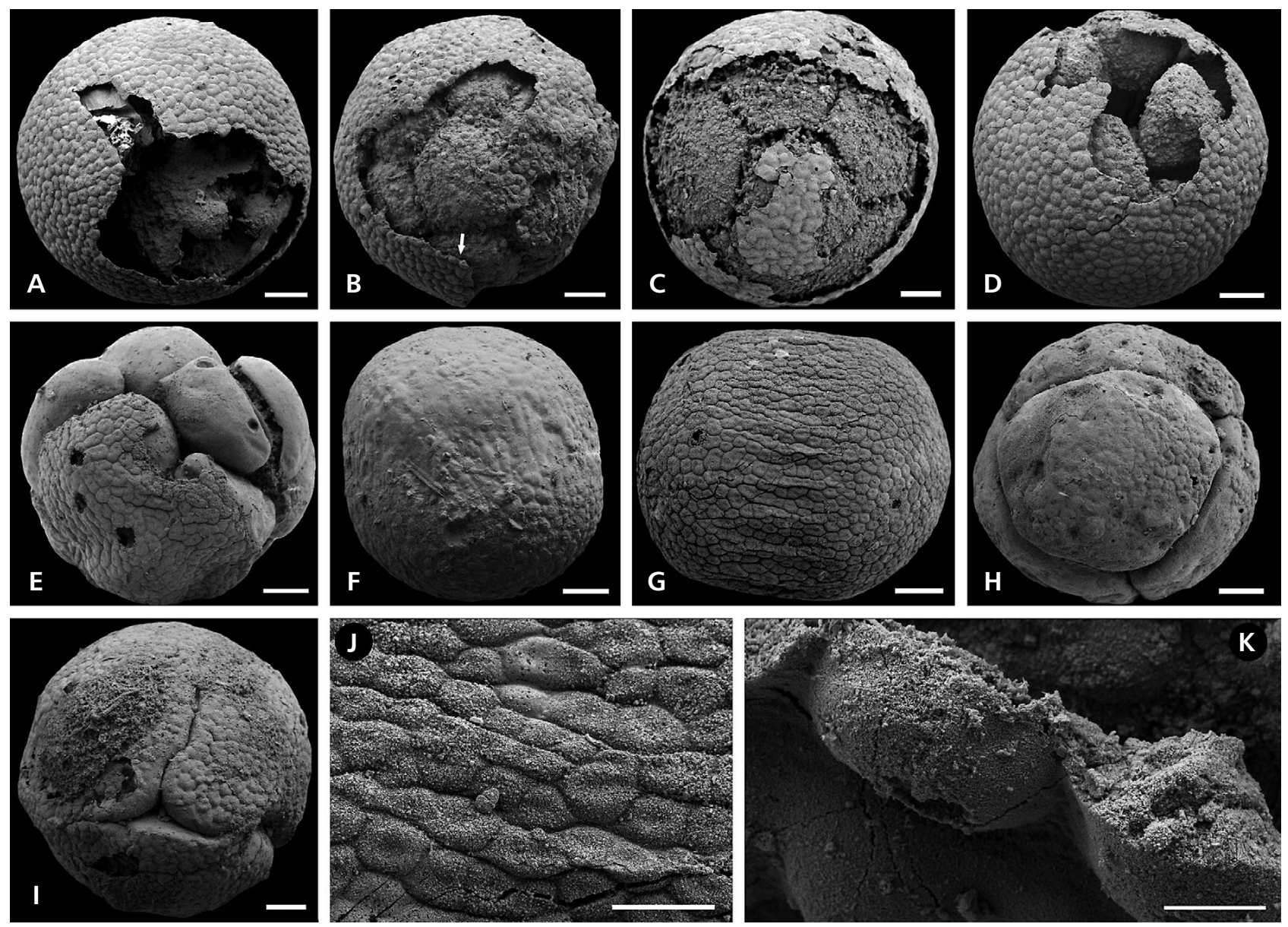

Figure 2. Megasphaera ornata (A) and Parapandorina raphospissa (B-I) with cell-like structure from the Weng' an Biota. $\bullet$ A - one internal body enclosed in an ornamented envelope with cell-like structure, notice the space between outer envelope and internal body. $\bullet$ B-E - samples show several internal blastomeres enclosed in a envelope with cell-like struture, notice no preservation of cytomembranes of blastomeres and phosphatic filiments and/or spherules on the surface of blastomeres in $\mathrm{B}, \mathrm{C}$ and $\mathrm{D}$. $\bullet \mathrm{F}, \mathrm{G}-$ embryo fossils probably undergoing mitosis, notice the shape change of polygons around the equator part. $\bullet \mathrm{H}, \mathrm{I}$ - 4-cell stage embryos without preservation of the outer capsule, showing imprint of the cell-like ornaments on the surface of blastomeres. $\bullet \mathrm{J}$ - a close-up view of G. $\bullet \mathrm{K}$ - magnified view of arrowed area in B, showing the details of envelope with cell-like structure. Scale bars represent $100 \mu \mathrm{m}$ for $\mathrm{A}-\mathrm{I}, 50 \mu \mathrm{m}$ for $\mathrm{J}$, and $10 \mu \mathrm{m}$ for $\mathrm{K}$.

in the same smooth peripheral plane as the normal ones (Fig. 2G, J). It is hard to imagine that the surface would retain its smoothness if it had been mechanically deformed.

Given the same size and envelope structure shared by the fossils shown in Fig. 2, they should be more closely related to each other than to the ornamented fossils shown in Fig. 1. From the perspective of developmental biology, these specimens with a different number of internal cells and the same cell-like polygons on the surface as shown in Fig. 2 may represent embryos of the same taxon at different cleavage stages. However, previous classification has treated these fossils as two different morphospecies. The fossil with only one internal cell (Fig. 2A) is assigned to Megashaera ornata, whereas the others with more than one internal cell (Fig. 2B-I) are named Parapandorina raphospissa. On the another hand, the fossils with various ornamentation patterns as shown in Fig. 1 may relate to different taxa (Xiao \& Knoll 2000), but they have all been assigned to one morphospecies Megashaera ornata. It is therefore clear that the morphological taxonomy of the Weng'an embryos conceals the biological affinities between different morphospecies, and hampers the estimation of the original biodiversity of the Weng' an embryos.

\section{Envelope microstructure of the ornamented spheroidal microfossils}

Interpretations of the Weng'an phosphatized microfossils vary greatly because of the difficulty in distinguishing primary biological features from diagenetic artifacts (e.g. Bengstson \& Budd 2004, Chen et al. 2004b). Unlike the phosphatized small shelly fossils, the Weng' an phosphatized microfossils show exquisite preservation of the cellular 
and subcellular structures (e.g. Hagadorn et al. 2006, Chen et al. 2009b). Although it still remains unclear how these embryo fossils preserved cellular details following phosphatization (Martin et al. 2003, 2005), and why taphonomic bias exists favouring the preservation of embryos in earlier cleavage stages (Dornbos et al. 2005) or embryos with a fertilization envelope (Raff et al. 2006), preservation analysis indicates that impregnation and encrustation were two principal phosphatization processes affecting the cell tissues of the Weng' an embryos (Xiao \& Knoll 1999, Xiao \& Schiffbauer 2009). In general, impregnation provides the best preservation of the primary biological structures and is characterized by randomly oriented fine apatite crystals (Fig. 5H, L, N), whereas encrustation usually adds diagenetic artifacts by producing isopachous rims with acicular or prismatic apatite crystals which are always perpendicular to the surface of original substrate (Fig. 5I, J, M, N). Since the envelope microstructure of the ornamented spheroidal microfossils are critical to their interpretation, it is important to distinguish the primary envelope (e.g. embryo chorion, vitelline membrane, and even plasma membrane, etc.) from diagenetic coatings and linings.

Based on SEM analyses, two major envelope categories and fossil morphologies of the ornamented spheroidal microfossils can be distinguished as shown in Figs 5, 6: 1) fossils with a thick multilayered envelope with various surface ornamentation patterns and a single internal cell (Fig. 6a); and 2) fossils exhbiting a single-layered envelope with the cell-like surface structure and several internal cells (amount is equal to $2^{\mathrm{n}}, \mathrm{n}=0,1,2,3 \ldots$ ) (Fig. 6b). In most cases, the thick multilayered envelope exhibits three layers, which are composed of randomly oriented fine apatite crystals, representing the primary structure (Fig. 5A-D, G, H). The inner layer tightly surrounding the internal body (cell) is interpreted to be phosphatized cytomembrane, which is usually thin and smooth (Fig. 5B, C). Sometimes, the inner capsule shows wrinkled and deformed structures which may be due to rapid syneresis or/and cytoplasm decay before mineralization, thus leading to an irregular space between the inner and middle layers (Fig. 5A, E). The phosphatic spherules and/or filaments within this space represent microbial activity during decay (Fig. 5A, E; Xiao \& Knoll 1999, 2000; Xiao \& Schiffbauer 2009). In such cases, an apatite coating could be deposited on the outer surface of the inner layer (Fig. 5E). Compared with the middle and outer layers, the inner cytoplasm membrane is poorly preserved (Fig. 5D). In some specimens, the inner layer is hardly distinguishable from the phosphatized cytoplasm (Fig. 5F), but an interface between the internal cell and the middle layer implies the presence of a flimsy membrane. One possible interpretation for the preservational bias is that the cytoplasm membrane is more fragile, allowing it to be more easily damaged during decay. In addition,

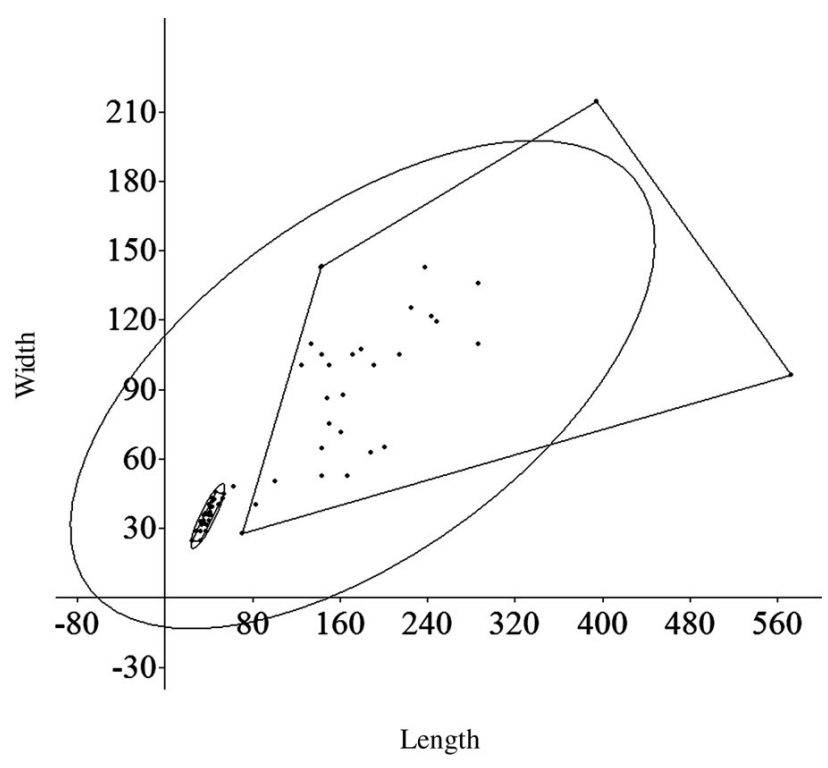

Figure 3. Scatter diagram showing the size stability of two kinds of polygons on the envelope surface of the ornamented spheroidal microfossils from the Weng'an Biota. The smaller 95\% ellipse and convex hull represent data from cell-like polygons, while the bigger $95 \%$ ellipse and convex hull represent the data from well-seamed polygons. Original statistical data are given in the Table 1.

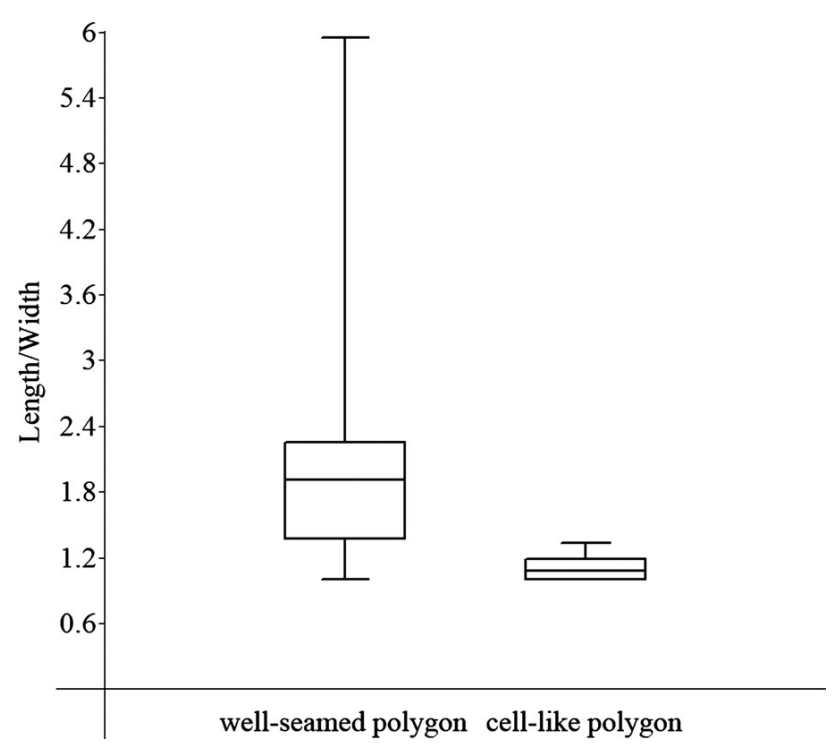

Figure 4. Box plot diagram showing the length/width ratio of two kinds of polygons on the envelope surface of the ornamented spheroidal microfossils from the Weng' an Biota. Original statistical data are given in the Table 1 .

more microbial activity might be expected to affect the cytoplasm, since it is usually filled with nutrient-rich substances, such as yolk granules and lipid drops, rather than the nutrient-poor chorion or diapause cyst of embryos (Xiao \& Knoll 1999).

The middle layer is much thicker than the inner cytomembrane (Fig. 5B, C, F). It is usually coated with an 
Table 1. Statistical data for the well-seamed polygons and cell-like polygons* on the envelope surface of the ornamented spheroidal microfossils from the Weng'an Biota. Abbreviations: * "length" and "width" are used to describe the polygons which have obvious long axis and short axis, $\sigma$ is standard deviation, and $\overline{\mathrm{A}}$ is mean value.

\begin{tabular}{|c|c|c|c|c|c|c|}
\hline \multirow[t]{2}{*}{ Number } & \multicolumn{3}{|c|}{ Well-seamed polygon } & \multicolumn{3}{|c|}{ Cell-like polygon } \\
\hline & $\begin{array}{l}\text { Length } \\
(\mu \mathrm{m})\end{array}$ & $\begin{array}{l}\text { Width } \\
(\mu \mathrm{m})\end{array}$ & $\mathrm{L} / \mathrm{W}$ & $\begin{array}{l}\text { Length } \\
(\mu \mathrm{m})\end{array}$ & $\begin{array}{l}\text { Width } \\
(\mu \mathrm{m})\end{array}$ & $\mathrm{L} / \mathrm{W}$ \\
\hline 1 & 150 & 100 & 1.5 & 28.6 & 28.6 & 1 \\
\hline 2 & 142.5 & 142.5 & 1 & 32.6 & 24.5 & 1.330612 \\
\hline 3 & 70 & 27.5 & 2.545455 & 40.8 & 36.7 & 1.111717 \\
\hline 4 & 82.5 & 40 & 2.0625 & 32.6 & 28.6 & 1.13986 \\
\hline 5 & 125 & 100 & 1.25 & 32.6 & 32.6 & 1 \\
\hline 6 & 237.5 & 142.5 & 1.666667 & 36.7 & 28.6 & 1.283217 \\
\hline 7 & 162.5 & 87.5 & 1.857143 & 28.6 & 28.6 & 1 \\
\hline 8 & 187.5 & 62.5 & 3 & 24.5 & 24.5 & 1 \\
\hline 9 & 150 & 75 & 2 & 37.1 & 36.4 & 1.019231 \\
\hline 10 & 200 & 65 & 3.076923 & 41.4 & 39.2 & 1.056122 \\
\hline 11 & 100 & 50 & 2 & 40.7 & 38.6 & 1.054404 \\
\hline 12 & 225 & 125 & 1.8 & 36.4 & 35.7 & 1.019608 \\
\hline 13 & 393.8 & 214.3 & 1.837611 & 40 & 35.7 & 1.120448 \\
\hline 14 & 285.7 & 135.7 & 2.10538 & 42.9 & 39.2 & 1.094388 \\
\hline 15 & 142.9 & 142.9 & 1 & 42.9 & 41.4 & 1.036232 \\
\hline 16 & 160.7 & 71.4 & 2.2507 & 42.9 & 42.9 & 1 \\
\hline 17 & 242.9 & 121.4 & 2.000824 & 37.1 & 35.7 & 1.039216 \\
\hline 18 & 178.6 & 107.1 & 1.6676 & 36.4 & 31.8 & 1.144654 \\
\hline 19 & 142.9 & 64.3 & 2.222395 & 40.9 & 36.4 & 1.123626 \\
\hline 20 & 214.3 & 104.8 & 2.044847 & 45.5 & 45.5 & 1 \\
\hline 21 & 142.8 & 104.8 & 1.362595 & 42.2 & 35.6 & 1.185393 \\
\hline 22 & 133.3 & 109.5 & 1.217352 & 44.4 & 42.2 & 1.052133 \\
\hline 23 & 247.6 & 119 & 2.080672 & 37.8 & 31.1 & 1.215434 \\
\hline 24 & 147.6 & 85.7 & 1.722287 & 40 & 35.6 & 1.123596 \\
\hline 25 & 285.7 & 109.5 & 2.609132 & 48.9 & 40 & 1.2225 \\
\hline 26 & 190.5 & 100 & 1.905 & 40 & 33.3 & 1.201201 \\
\hline 27 & 61.9 & 47.6 & 1.30042 & 35.6 & 35.6 & 1 \\
\hline 28 & 171.4 & 104.8 & 1.635496 & 53.3 & 44.4 & 1.20045 \\
\hline 29 & 142.8 & 52.4 & 2.725191 & 40 & 40 & 1 \\
\hline 30 & 571.4 & 96.2 & 5.939709 & 35.6 & 33.3 & 1.069069 \\
\hline 31 & 166.7 & 52.4 & 3.181298 & 33.3 & 31.1 & 1.07074 \\
\hline 32 & 28.6 & 28.6 & 1 & 40 & 35.6 & 1.123596 \\
\hline 33 & 52.4 & 42.8 & 1.224299 & 37.8 & 31.1 & 1.215434 \\
\hline$\sigma$ & & & 0.915794 & & & 0.091968 \\
\hline$\overline{\mathrm{A}}$ & & & 2.023985 & & & 1.098572 \\
\hline$\sigma / \overline{\mathrm{A}}$ & & & 0.452471 & & & 0.083716 \\
\hline
\end{tabular}

isopachous rim (2-5 $\mu \mathrm{m}$ thick) consisting of prismatic apatite crystals perpendicular to inner, outer or both sides (Fig. 5I, M, Xiao \& Knoll 1999, Xiao \& Schiffbauer 2009). The outer layer (Fig. 6a) is more easily identifiable because of the various ornaments on its outer surface (Fig. 5A-F). The maximum thickness of the outer layer is up to $30-40 \mu \mathrm{m}$ (Fig. 5C, M, N). A crescent cavity (view from cross-section) between the outer and middle layers is common and has a similar size and shape in different specimens (Fig. 5B, C, D, F). Phosphatic filaments and/or spherules representing microbial activities are also found within the cavity (Fig. 5C, D, F, I, J). The regular shape and uniform size of the cavity as well as the filaments inside not only indicate that the cavity existed before mineralization, but also suggest that it is probably a primary biological structure rather than taphonomic artifact. Beyond the area of the crescent cavity, a clear slit as the boundary between the middle and outer layers can still be identified at higher magnification (Fig. 5B, K, L). The randomly oriented apatite crystals on both sides of the slit suggest that they are impregnated primary capsules (Fig. 5L, Xiao \& Schiffbauer 2009), but not secondary artifacts. The two layers usually merge into one thicker layer in most specimens (Fig. 5C, F, M). Only one internal body was found in the ornamented spheroidal microfossils with a multilayered envelope based on examination of more than ten thousand specimens of the ornamented microfossils.

The envelope of the spheroidal microfossils with cell-like surface structure is a thin capsule, about 2-10 $\mu \mathrm{m}$ in thickness (Fig. 2K). As shown by Fig. 6, these microfossils do not exhibit a middle layer except for the inner cytomembrane of internal cells or blastomeres (Fig. 2A-E), and the outer capsule with a cell-like structure (Fig. 2K). This inference is further supported by the impressions of cell-like structure on the surface of the internal blastomeres (Fig. 2H-I). All the observations above suggest that these morphological and structural differences between the two categories of ornamented embryos (eggs) are biogenetic rather than artifacts resulted from taphonomic process.

\section{Conclusions and discussion}

In summary, there are two gross categories (A-type and B-type in Fig. 6) of the sculptured spheroidal microfossils in the Weng'an Biota. With the exception of the phosphatized cytomembrane of internal cells or blastomeres (Fig. 6-aI, bI), the A-type fossils have a two-layered envelope (Fig. 6-aO, aM) enclosing only a single internal body, which has been previously assigned to Megasphaera ornata. The B-type fossils possess a single-layered envelope surrounding several internal bodies $\left(2^{\mathrm{n}}, \mathrm{n}=0,1,2,3 \ldots\right)$, which have been previously assigned to Megasphaera ornata (when $\mathrm{n}=0$, Fig. 2A) or Parapandorina raphospissa (when $\mathrm{n}>0$ ). All these sculptured spheroidal microfossils have been previously regarded as metazoan eggs or embryos during the diapause stage. Based on comparisons 

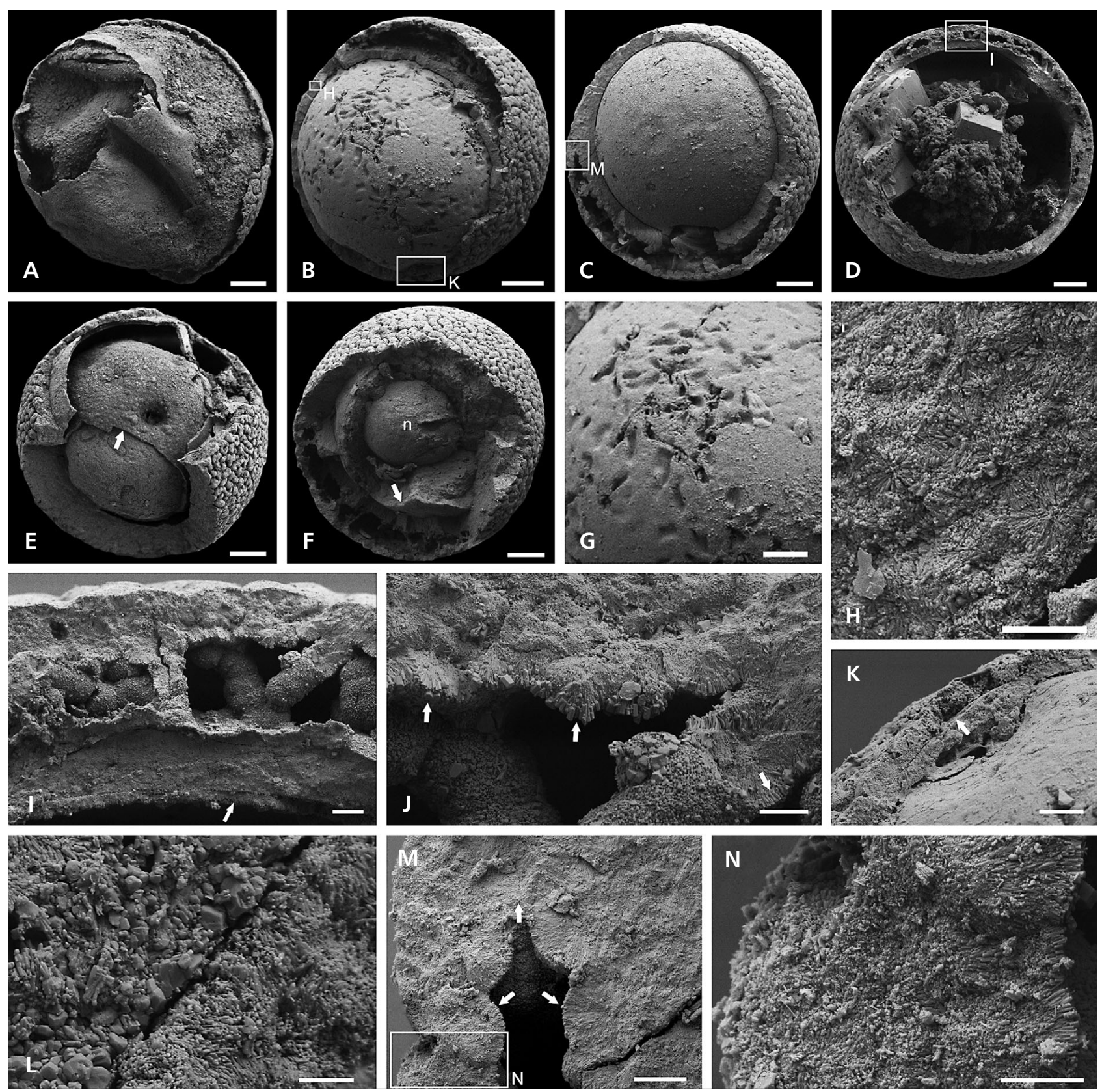

Figure 5. Envelope microstructures and internal body of Megasphaera ornata from the Weng' an Biota. $・ \mathrm{~A}-\mathrm{F}-$ the ornamented fossils encircled by three original capsules. The inner and middle layers of A folded; notice a regular cresent cavity with phosphatized filiments and/or spherules between outer and middle capsules in B-D and F; the internal cell of D strongly degraded, notice the giant idiomorphic crystals of pyrite; the inner layer are covered by phosphatic spherules and coating in A and $\mathrm{E}$; nucleolus is preserved in $\mathrm{F}(\mathrm{n}) \cdot \bullet \mathrm{G}$ - magnified view of $\mathrm{B}$, showing deformation on the surface of the inner layer. $\bullet \mathrm{H}$ - magnification of the box area in B (left up), showing randomly oriented apatite crystals. $\bullet \mathrm{I}-$ magnification of the box area in D, showing space between ornamented outer and middle layers, notice the phosphatic filiments inside the cavity and lining on inner surface of the middle layer (arrow). $\bullet \mathrm{J}$ - close-up view of I, showing more details of the inner surface of the outer layer and filiments, notice the isopachous prismatic apatite crystals perpendicular to the inner surface of the outer layer and outer surface of filaments (arrows). $\bullet \mathrm{K}-$ magnification of the boxed area of B (right down), showing slit between out and middle layers (arrow). $\bullet \mathrm{L}$ - magnified view of $\mathrm{K}$, showing randomly oriented crystals distributed on both sides of the slit. $\bullet \mathrm{M}$ - magnification of the boxed area of $\mathrm{C}$, showing no obvious boundary between the out and middle layers beyond the cavity (upper arrow). Notice coatings on the outer surface of the middle layer and the inner surface of the outer layer (lower arrows). $\bullet \mathrm{N}$ - magnification of the boxed area of $\mathrm{M}$, notice an isopachous rim with inward growing crystals of apatite perpendicular to the inner surface of the outer layer. Scale bars are equal to $100 \mu \mathrm{m}$ for A to $\mathrm{F}, 50 \mu \mathrm{m}$ for $\mathrm{G}, 10 \mu \mathrm{m}$ for I and $\mathrm{M}, 25 \mu \mathrm{m}$ for $\mathrm{K}, 5 \mu \mathrm{m}$ for $\mathrm{H}, \mathrm{J}$ and $\mathrm{N}$, and $2.5 \mu \mathrm{m}$ for $\mathrm{L}$. 

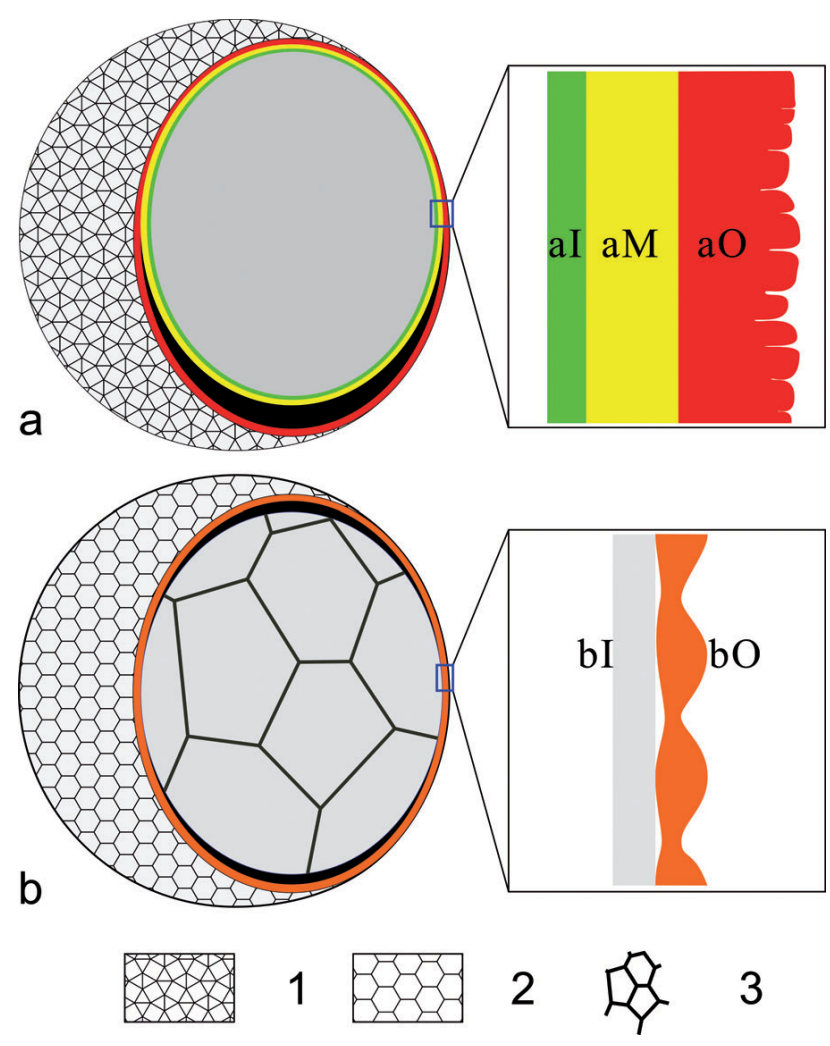

Figure 6. Sketch diagram showing two types of the Weng'an ornamented embryos. a - typical Megasphaera ornata; b - sculptured Parapandorina raphospissa; Legends: 1 - ornamentations on outer envelope of Megasphaera ornata; 2 - cell-like structure of envelope of Parapandorina raphospissa; 3 - internal blastomeres; I - inner layer; $\mathrm{M}$ - middle layer; $\mathrm{O}$ - outer layer.

with the diapause embryos of modern aquatic invertebrates, however, we propose that the diapause embryo hypothesis can be only adapted for the A-type fossils, while the B-type fossils probably represent normal developing embryos at an early holoblastic cleavage stage.

Diapause is a common physiological state for embryos in a number of extant invertebrates (Belmonte et al. 1997, Cáceres 1997), and even some vertebrates (Murphy \& Collier 1997, Hrbek \& Larson 1999). Diapause embryos are generally characterized by the following features: 1) thick and multilayered diapause cysts directly outside of the plasma membrane (Santella \& Ianora 1990, Belmonte \& Puce 1994, Marcus 1996, Castro-Longoria 2001, Couch et al. 2001); the cyst consists of at least the cortical and alveolar layers (Gilchrist 1978, Blades-Eckelbarger \& Marcus 1992, Dharani \& Altaff 2004, Liu et al. 2009); 2) taxon-specific ornamentation pattern on the outer surface of the diapause cyst (Gilbert \& Wurdak 1978, Belk 1989, Shen \& Huang 2008); and 3) diapause only occurs at a specific developmental stage for each species (Ianora \& Santella 1991). The multilayered envelope and diverse ornamentation patterns of the A-type fossils are comparable to those known from extant diapause embryos. The outer and middle layers of the envelopes of the A-type fossils are comparable to the cortical and alveolar layers of the resting cysts, whilst the crescent-shaped cavity between the outer and middle layers in the fossils is a possible analog for the subcortical spaces of extant diapause embryos (Gilchrist 1978, Liu et al. 2009). The complex surface ornaments are similar to that of extant diapause eggs, such as those of branchiopod arthropods (Mura 2001).

Unlike for the A-type fossils, the envelope of the B-type fossils does not show multilayered microstructure, and it is only a thin capsule which is more alike the textured fertilization membrane (developed from vitelline membrane) of the non-diapause embryos of modern metazoans, e.g. annelids, molluscans, and arthropods (Santella \& Ianora 1990, Conn 1991, Castro-Longoria 2001). The B-type fossils with a single capsule also resemble extant mature subitaneous eggs (Santella \& Ianora 1990, Conn 1991, Ianora \& Santella 1991, Couch et al. 2001). In addition, the outer capsule, which shows elongated cell structure in some specimens (Fig. 2F, G) and is reminiscent of mitosis, further rules out the interpretation of the thin capsule with cell-like structure as a diapause cyst. This is because once diapause initiates, the embryo enters a state of extremely low metabolism, during which embryonic development almost stops. By contrast, shape change of the fertilization membrane during cleavage in non-diapause embryos is a common phenomenon (Conn 1991). Another line of evidence to support the non-diapause interpretation of B-type fossil embryos is the discovery of specimens at various stages of holoblastic cleavage. As shown by Fig. 2A-E, some specimens have different numbers of blastomeres which are enclosed in an envelope with the same microstructure, suggesting they are non-diapause embryos of the same organism at various holoblastic cleavage stages. As mentioned above, diapause only occurs at a specific development stage for each species, for example, resting eggs of Anomalocera patersoni (copepod) arrest development at the 32-cell stage and remain at this stage until diapause breaks (Ianora \& Santella 1991). Thus, the possibility of fossil embryos of one organism with preservation of the same number of blastomeres would be much higher if they were at a diapause stage which usually lasts for several months or even years, but this is not the case for the B-type fossils.

Chen et al. (2009a) interpreted the cell-like polygons on the surface of the B-type fossils as follicle cells. However, extant embryos which exhibit follicle cells usually possess capsules between the cell plasma membrane and the follicle cell layer (Villa \& Patricolo 1987, Pennington et al. 1999, Buckland-Nicks \& Hodgson 2000), but such capsules are not found in the B-type fossils. The document about ripe oocyte directly in the follicle cell layer without a vitelline membrane is unknown in Eumetazoa (Conn 1991, Gilbert \& Raunio 1997, Schoenwolf 2009). 
The A-type fossils are more abundant than the B-type fossils in the Weng' an embryos, providing additional support to our interpretation. Because diapause cysts are more resistant against decay than the fertilization membrane, and could survive in sediments for a very long time, even several years or more than a century (Hairston et al. 1995, Engel \& Hirche 2004, Belmonte \& Pati 2007), this would lead to taphonomic bias toward preservation of diapause cysts. In addition, the extreme high density of diapause eggs in modern sediments, for example, the density of copepod diapause eggs can reach $2 \times 10^{5}$ eggs $/ \mathrm{m}^{2}$ (Hairston et al. 1995), provide a reasonable interpretation for why the diapause embryo fossils are so abundant in the Weng' an Biota.

Interpretation of the Weng' an phosphatized embryos is like a "Rorschach Inkblot Test" to paleontologists; the answers are always different. Taphonomic bias and diagenetic artifacts provide reasons for this on the one hand, while the lack of knowledge about the complex embryonic development of the earliest animals provides a further challenge on the other. For example, the resting cyst of Boeckella triarticulata (copepod) can be seen to be composed of five layers under transmission electron microscopy (Couch et al. 2001). If such a kind of microstructure was present in the Weng'an embryos, it would have been lost during phosphatization. Likewise, the fertilization envelopes of the subitaneous eggs of some living animals are also multilayered, e.g. Sinodiaptomus indicus (copepod, Dharani \& Altaff 2004). Nevertheless, we believe that assessment of the Weng'an ornamented embryos through taphonomic tests and comparison to extant embryos will provide further useful information to solve this dilemma.

\section{Acknowledgements}

This work is supported by the Chinese Academy of Sciences (KZCX-YW-Q08-4) and National Natural Science Foundation of China (40725005, 40930211, 41023008, J0930006). We thank Xiao Shuhai (Virginia Tech) for helpful comments on the manuscript; Wang Chunzhao and Meng Yuanying (NIGPAS) assisted in the scanning electron microscopy and acetic acid digestion of rock samples, respectively.

\section{References}

BELK, D. 1989. Identification of species in the conchostracan genus Eulimnadia by egg shell morphology. Journal of Crustacean Biology 9(1), 115-125. DOI 10.2307/1548453

Belmonte, G., Miglietta, A., Rubino, F. \& Boero, F. 1997. Morphological convergence of resting stage of planktonic organisms: a review. Hydrobiologia 355, 159-165. DOI 10.1023/A:1003071205424

Belmonte, G. \& PAti, C.A. 2007. Hatching rate and diapause duration in eggs of Paracartia latisetosa (Copepoda: Calanoida).
Journal of Plankton Research 29, i39-i47.

DOI 10.1093/plankt/fbl064

Belmonte, G. \& Puce, M. 1994. Morphological aspects of subitaneous and resting eggs from Acartia josephinae (Calanoida). Hydrobiologia 292/293, 131-135.

DOI 10.1007/BF00229932

Bengtson, S. \& Budd, G. 2004. Comment on "small bilaterian fossils from 40 to 55 million years before the Cambrian". Science 306, 1291a. DOI 10.1126/science.1101338

Blades-Eckelbarger, P.I. \& Marcus, N.H. 1992. The origin of cortical vesicles and their role in egg envelope formation in the "spiny" eggs of a calanoid copepod, Centropages velificatus. Biology Bulletin 182, 41-52. DOI 10.2307/1542179

Britz, R., Koкоscha, M. \& Riehl, R. 1995. The anabantoid genera Ctenops, Luciocephalus, Parasphaerichthys, and Sphaerichthys (Teleostei: Perciformes) as a monophyletic group: evidence from egg surface structure and reproductive behaviour. Japan Journal of Ichthyology 42(1), 71-79.

Buckland-Nicks, J. \& Hodgson, A.N. 2000. Fertilization in Callochiton castaneus (Mollusca). Biology Bulletin 199, 59-67. DOI 10.2307/1542707

CÁCERES, C.E. 1997. Dormancy in invertebrates. Invertebrate Biology 116(4), 371-383. DOI 10.2307/3226870

CAStro-Longoria, E. 2001. Comparative observations on the external morphology of subitaneous and diapause eggs of acartia species from Southampton Water. Crustaceana 74(3), 225-236. DOI 10.1163/156854001505479

CHEn, J.Y. 2004. The dawn of animal world. 104 pp. Jiangsu Press of Science and Technology, Nanjing. [in Chinese]

Chen, J.Y., Bottuer, D.J., Davidson, E.H., Dornbos, S.Q., GaO, X., Yang, Y.H., Li, C.W., LI, G., Wang, X.Q., XIAN, D.C., Wu, H.J., Hwu, Y.K. \& TAFforeau, P. 2006. Phosphatized polar lobe-forming embryos from the Precambrian of Southwest China. Science 312, 1644-1646. DOI 10.1126/science.1125964

Chen, J.Y., Bottuer, D.J, Davidson, E.H., Li, G., Gao, F., Cameron, R.A., Hadfield, M.G., Xian, D.C., Tafforeau, P., JiA, Q.J., SugiYAmA, H. \& TANG, R. 2009a. Phase contrast synchrotron X-ray microtomography of Ediacaran (Doushantuo) metazoan microfossils: phylogenetic diversity and evolutionary implications. Precambrian Research 173, 191-200. DOI 10.1016/j.precamres.2009.04.004

Chen, J.Y., Bottuer, D.J., Li, G., Hadfield, M.G., Gao, F., Cameron, A.R., Zhang, C.Y., Xian, D.C., Tafforeau, P., LiaO, X. \& Yin, Z.J. 2009b. Complex embryos displaying bilaterian characters from Precambrian Doushantuo phosphate deposits, Weng' an, Guizhou, China. Proceedings of $\mathrm{Na}$ tional Academy of Sciences of the United States of America 106, 19056-19060. DOI 10.1073/pnas.0904805106

Chen, J.Y., BottJer, D.J., Oliveri, P., Dornbos, S.Q., Gao, F., Ruffins, S., Chi, H.M., Li, C.W. \& Davidson, E.H. 2004a. Small bilaterian fossils from 40 to 55 million years before the Cambrian. Science 305, 218-222. DOI 10.1126/science.1099213

Chen, J.Y. \& CHI, H.W. 2005. Precambrian phosphatized embryos and larvae from the Doushantuo Formation and their af- 
finities, Guizhou (SW China). Chinese Science Bulletin 50, 1750-1757.

Chen, J.Y., Oliveri, P., Davidson, E.H. \& BotTJer, D.J. 2004b. Response to comment on "Small bilaterian fossils from 40 to 55 million years before the Cambrian”. Science 306, $129 \mathrm{lb}$.

Chen, J.Y., Oliveri, P., Gao, F., Dornbos, S.Q., Li, C.W., BotTJER, D.J. \& DAvidson, E.H. 2002. Precambrian animal life: Probable developmental and adult cnidarian forms from Southwest China. Developmental Biology 248, 182-196. DOI 10.1006/dbio.2002.0714

Chen, J.Y., Oliveri, P., Li, C.W., Zhou, G.Q., Gao, F., Hagadorn, J.W., Peterson, K.J. \& Davidson, E.H. 2000. Precambrian animal diversity: Putative phosphatized embryos from the Doushantuo Formation of China. Proceedings of $\mathrm{Na}$ tional Academy of Sciences of the United States of America 97, 4457-4462. DOI 10.1073/pnas.97.9.4457

Chi, H.M., Chen, J.Y. \& Li, C.W. 2003. Early developmental eggs with perivitelline space from Precambrian Weng'an Fauna, Weng' an, central Guizhou (South China). Acta Palaeontologica Sinica 42(3), 448-451. [in Chinese with English abstract]

Cohen, P.A., Knoll, A.H. \& Kodnerc, R.B. 2009. Large spinose microfossils in Ediacaran rocks as resting stages of early animals. Proceedings of National Academy of Sciences of the United States of America 106, 6519-6524.

DOI 10.1073/pnas.0902322106

Condon, D., Zhu, M.Y., Bowring, S., WAng, W., YAng, A.H. \& JIN, Y.G. 2005. U-Pb ages from the Neoproterozoic Doushantuo Formation, China. Science 308, 95-98. DOI 10.1126/science. 1107765

ConN, D.B. 1991. Atlas of Invertebrate Reproduction and Development. 252 pp. Wiley-Liss, New York.

Couch, K.M., Downes, M. \& Burns, C.W. 2001. Morphological differences between subitaneous and diapause eggs of Boeckella triarticulata (Copepoda: Calanoida). Freshwater Biology 46, 925-933.

DOI 10.1046/j.1365-2427.2001.00727.x

Dharani, G. \& Altaff, K. 2004. Ultra structure of subitaneous and diapausing eggs of planktonic copepod Sinodiaptomus (Rhinediaptomus) indicus. Current Science 87(1), 109-112.

Dornbos, Q.S., Bottjer, D.J., Chen, J.Y., Gao, F., Oliveri, P. \& LI, C.W. 2006. Environmental controls on the taphonomy of phosphatized animals and animal embryos from the Neoproterozoic Doushantuo Formation, southwest China. Palaios 21, 3-14. DOI 10.2110/palo.2004.p04-37

Dornbos, Q.S., Bottjer, D.J., Chen, J.Y., Oliveri, P., Gao, F. \& LI, C.W. 2005. Precambrian animal life: Taphonomy of phosphatized metazoan embryos from southwest China. Lethaia $38,101-109$. DOI 10.1080/00241160510013187

ENGEL, M. \& HIRChE, H.-J. 2004. Seasonal variability and interspecific differences in hatching of calanoid copepod resting eggs from sediments of the German Bight (North Sea). Journal of Plankton Research 26(9), 1083-1093.

DOI 10.1093/plankt/fbh099

Gilbert, J.J. \& WuRDAK, E.S. 1978. Species-specific morphology of resting eggs in the rotifer Asplanchna. Transactions of the American Microscopical Society 97(3), 330-339. DOI $10.2307 / 3225986$

GilberT, S.F. \& RAUNIO, A.M. 1997. Embryology: constructing the organism. 537 pp. Sinauer Associates, Sunderland.

GiLchrist, B.M. 1978. Scanning electron microscope studies of the egg shell in some Anostraca (Crustacea: Branchiopoda). Cell Tissue Research 193, 337-351.

DOI 10.1007/BF00209045

Hagadorn, J.W., Xiao, S.H., Donoghue, P.C.J., Bengtson, S., Gostling, N.J., Pawlowska, M., Raff, E.C., Raff, R.A., Turner, F.R., Yin, C.Y., Zhou, C.M., Yuan, X.L., McFeely, M.B., Stampanoni, M. \& Nealson, K.H. 2006. Cellular and subcellular structure of Neoproterozoic animal embryos. Science 314, 291-294. DOI 10.1126/science.1133129

Hairston, N.G., Van Brunt, R.A., Kearns, C.M. \& Engstrom, D.R. 1995. Age and survivorship of diapause eggs in a sediment egg bank. Ecology 76(6), 1706-1711.

Hrbek, T. \& Larson, A. 1999. The evolution of diapause in the killifish family Rivulidae (Atherinomorpha, Cyprinodotiformes): a molecular phylogenetic and biogeographic perspective. Evolution 53(4), 1200-1216.

IAnoRA, A. \& Santella, L. 1991. Diapause embryos in the neustonic copepod Anomalocera patersoi. Marine Biology 108, 387-394.

Li, C.W., Chen, J.Y. \& HuA, T.E. 1998. Precambrian sponges with cellular structures. Science 279(5352), 879-882. DOI 10.1126/science.279.5352.879

Liu, P.J., Xiao, S.H., Yin, C.Y., Zhou, C.M., Gao, L.Z. \& Tang, F. 2008. Systematic description and phylogenetic affinity of tubular microfossils from the Ediacaran Doushantuo Formation at Weng' an, South China. Palaeontology 51, 339-366.

Liu, Y.L., Zhao, Y., Dai, Z.M., Chen, H.M. \& Yang, W.J. 2009. Formation of diapause cyst shell in brine shrimp Artemia parthenogenetica, and its resistance role in environmental stresses. Journal of Biological Chemistry 284(25), 16931-16938.

Marcus, N.H. 1996. Ecological and evolutionary significance of resting eggs in marine copepods: past, present, and future studies. Hydrobiologia 320, 141-152.

Martin, D., Briggs, D.E.G. \& PARKes, R.J. 2003. Experimental mineralization of invertebrate eggs and the preservation of Neoproterozoic embryos. Geology 31, 39-42.

Martin, D., Briggs, D.E.G. \& Parkes, R.J. 2005. Decay and mineralization of invertebrate eggs. Palaios 20, 562-572.

MurA, G. 2001. Morphological diversity of the resting eggs in the anostracan genus Chirocephalus (Crustacea, Branchiopoda). Hydrobiologia 450, 173-185.

Murphy, W.J. \& Collier, G.E. 1997. A molecular phylogeny for aplocheiloid fishes (Atherinomorpha, Cyprinodotiformes): the role of vicariance and the origins of annualism. Molecular Biology and Evolution 14(8), 790-799.

Pennington, J.T., Tamburri, M.N. \& Barry, J.P. 1999. Development, temperature tolerance, and settlement preference of embryos and larvae of the articulate brachiopod Laqueus californianus. Biology Bulletin 196, 245-256.

Raff, E.C., Villinski, J.T., Turner, R.T., Donoghue, P.C.J. \& 
RAFF, R.A. 2006. Experimental taphonomy shows the feasibility of fossil embryos. Proceedings of National Academy of Sciences of the United States of America 103, 5846-5851. DOI 10.1073/pnas.0601536103

SANTElla, L. \& IANORA, A. 1990. Subitaneous and diapause eggs in Mediterranean populations of Pontella mediterranea (Copepoda: Calanoida): a morphological study. Marine Biology 105, 83-90. DOI 10.1007/BF01344273

SCHOENwolf, G.C. 2009. Laboratory studies of vertebrate and invertebrate embryos: guide and atlas of descriptive and experimental development. 388 pp. Benjamin Cummings, San Francisco.

Shen, Y.B. \& Huang, D.Y. 2008. Extant clam shrimp egg morphology: taxonomy and comparison with other fossil branchiopod eggs. Journal of Crustacean Biology 28(2), 352-360. DOI 10.1651/0278-0372(2008)028[0352:ECSEMT]2.0.CO;2

Villa, L. \& PAtricolo, E. 1987. A scanning electron microscope study of Ascidia malaca egg (Tunicate), changes in the cell surface morphology at fertilization. Biology Bulletin 173, 355-366. DOI 10.2307/1541548

Xiao, S.H., Hagadorn, J.W., Zhou, C.M. \& Yuan, X.L. 2007. Rare helical spheroidal fossils from the Doushantuo Lagerstätte: Ediacaran animal embryos come of age? Geology 35, 115-118. DOI 10.1130/G23277A.1

Xiao, S.H. \& KNoll, A.H. 1999. Fossil preservation in the Neoproterozoic Doushantuo phosphorite Lagerstätte, South China. Lethaia 32, 219-240.

DOI 10.1111/j.1502-3931.1999.tb00541.x

XiaO, S.H. \& Knoll, A.H. 2000. Phosphatized animal embryos from the Neoproterozoic Doushantuo Formation at Weng'an, Guizhou, South China. Journal of Paleontology 74(5), 767-788.

DOI 10.1666/0022-3360(2000)074<0767:PAEFTN>2.0.CO;2

XIAO, S.H. \& SchiffbauER, J.D. 2009. Microfossils phosphati- zation and its astrobiological implications, 89-117. In SECKBaCh, J. \& Walsh, M. (eds) From Fossils to Astrobiology. Springer, Berlin.

XiaO, S.H., Yuan, X.L. \& Knoll, A.H. 2000. Eumetazoan fossils in terminal Proterozoic phosphorites? Proceedings of $\mathrm{Na}$ tional Academy of Sciences of the United States of America 97, 13684-13689. DOI 10.1073/pnas.250491697

Xiao, S.H., Zhang, Y. \& Knoll, A.H. 1998. Three-dimensional preservation of algae and animal embryos in a Neoproterozoic phosphorite. Nature 391, 553-558. DOI 10.1038/35318

XıAO, S.H., Zhou, C.M. \& YuAN, X.L. 2007b. Undressing and redressing Ediacaran embryos. Nature 446, E9. DOI 10.1038/nature05753

Yin, C.Y., Bengtson, S. \& Yue, Z. 2004. Silicified and phosphatized Tianzhushania from the Neoproterozoic Doushantuo phosphorites at Weng'an, Guizhou, South China. Acta Palaeontologica Polonica 49(1), 1-12.

Yin, L.M., Zhu, M.Y., Knoll, A.H., YuAN, X.L., Zhang, J.M. \& Hu, J. 2007. Doushantuo embryos preserved inside diapause egg cysts. Nature 446, 661-663.

DOI 10.1038/nature05682

Yin, L.M., Zhou, C.M. \& YuAn, X.L. 2008. New data on Tianzhushania: an Ediacaran diapauses egg cyst from Yichang, Huibei. Acta Palaeontologica Sinica 47(2), 129-140. [in Chinese with English abstract]

Yuan, X.L., XiaO, S.H., Yin, L.M., Knoll, A.H., Zhou, C.M. \& Mu, X.N. 2002. Doushantuo fossils: life on the eve of animal radiation. $171 \mathrm{pp}$. University of Science and Technology of China Press, Heifei, China. [in Chinese with English summary]

Zhu, M.Y., Zhang, J.M. \& YANG, A.H. 2007. Integrated Ediacaran (Sinian) chronostratigraphy of South China. Palaeogeography, Palaeoclimatology, Palaeoecology 254, 7-61. DOI 10.1016/j.palaeo.2007.03.025 